\title{
Informal Ties Among Conscripts in a Given Military Unit
}

\author{
Sinan Çaya ${ }^{a}$
}

\begin{abstract}
In any military environment, certain cohesive forces are required for a smooth functioning, regarding accomplishment of the given mission. One of the most prominent issues from the point of view of good motivation and high morale is equity, which should definitely be imposed by leaders and taken for granted by the rank-and-file members. All military people in a certain military unit invariably keep comparing themselves with fellow soldiers: What do they contribute and what reward do they receive, in return? Is the balance fair or unfair? In reality, disturbances in equity may occur in various forms. Some are tolerable due to the specific character of the environment in question. But beyond a certain limit, they are disruptive of a peaceful atmosphere. The most effective cohesive force, which in turn is strongly affected and in a sense utterly determined by the satisfaction of the need for a just and fair ambiance, is the concept of comradeship. Indeed, it gets further intensified in combat circumstances. It is also this very feeling which is always pleasantly recalled even long years after the service is finished.
\end{abstract}

Keywords

Comradeship, cohesive printing houses, military

In any given military environment, merely by the nature of the expected tasks of defense, the existence of some cohesive forces is universally essential to maintain a peaceful climate, e.g., a we-feeling, coperation, and solidarity. This is a sheer necessity regardless of the specific national and/or cultural "texture".

\section{A FEELING THAT ORDERS ARE JUSTLY ISSUED}

Obviously, one such force is the concept of equity. Each person within a given military unit should feel that justice and righteousness prevail. Accordingly, exposure to danger, share of the difficulties and "drudgery", and allocation of privileges should be uniformly distributed.
Good and humanly conduct (see Figure 1) is a must. Establishment and maintenance of equity are especially achieved through leader role models, whose deeds are consistent with what they "preach" in words .

We encounter one such remarkable fictitious character in a story (Defender of the Faith) of Philip Roth (1959). The plot unravels in a boot camp in Missouri in May 1945. A sly soldier, Sheldon, attempts to take advantage of the new sergeant Nathan

asstanbul University, Turkey

Correspondent Author:

Sinan Çaya, Instructor of Social Graduate Elective Courses at Istanbul University, Institute of Marine Administration and Sciences, Istanbul, Turkey

E-mail: sinan.caya@gmail.com 
Marx, a Jewish-American like himself. He first squeezes permission for attending the synagouge, which Max obtains from Captain Barrett, for his sake. But the sergeant overhears Sheldon's saying "let the others clean the barracks". Sheldon later reports the non-kosher food to a senator by mail, despite the Rabbi Major's suggestion that it is okey to put up with eating trafe (unfit/improper) under the given military circumstances. Sheldon's various abuses accumulate, culminating in his arrangement of his prospective movement to New Jersey as the only exception, while all others are destined to the battle-rich Pacific. But in the end, through a phone call to the acquaintances placed in the high quarters, Max makes it sure that this exceptionally-issued order is cancelled. Ironically, he resorts to a trick to achive his revenge: He simply affirms that this specific soldier is especially craving for the Pacific Ocean region, in order to avenge his fallen brother, on the battle-field! Eventually deceitful Sheldon also ends up in the Pacific region like everyone else in the boot camp.

\section{AVOIDING HARDSHIPS BY SNEAKING AWAY}

However, a cunning individual who is morally weak and who possesses other means, may "goldbrick" by resorting to other socially unacceptable ways.

Some examples are malingering sickness while relying on relations in the medical corps to "confirm" one's "unhealthy" situation, trusting influential acquaintances and making them "pull a few strings" for his sake, stooping to excessive flattery in order to win favor of figures of authority, or simply allocating one's financial capabilities like treating sergeants and corporals to tea, expensive cigarettes, or even movies and lunches downtown on weekend permissions, etc.

Conversely, a gullibly naive person may be given more than his share of the work. The poor man then always puts up with drudgery! What a bitter lot for a soldier! An anonymous anecdote is also relevant here:
The naive soldier was about to complete his service. His fellow soldiers came together and wanted to relieve their guilt feelings. They said to him: "Please forgive our unfairness. We made you work too hard. The few days ahead of you will be your rest days. You will just enjoy yourself!". The poor man got moved. With tears in his eyes, he replied: "In that case, as of today, I will quit urinating into your food!".

\section{WE-FEELING}

One special sociological concept inherent to the army is the military comradeship. Genuine forms of military comradeship usually develop in stressful situations and especially in combat.

In extreme danger and need, there is undeniably a minimal satisfaction in having others of your own species in your vicinity. The proverb "misery loves company" has its basis $^{1}$ particularly in situations where defense and aggression are involved... This confraternity of danger and exposure is unequaled in forging links among people of unlike desire and temperament. Numberless soldiers have died, more or less willingly, not for country or honor or religious faith or for any abstract good, but because they realized that by fleeing their post and rescuing themselves, they would expose their companions to greater danger. Such loyalty to the group is the essence of fighting morale. The commander who can preserve and strengthen it knows that all other physical factors are little in comparison. (Gray 1970: 27, 40-41)

\section{COMPATRIOTSHIP}

The idea of compatriotship and fraternization (which now is horrified in the U.S. military when it occurs between two wide-apart ranks) was an important concept for the American soldier way back in 1860s, during the American Civil War and the Spanish-American War days:

America (at the time of the Civil War) was not an urban and industrial country, but a society of farmsteads and small towns. The army was not the twentieth century army, either. Units were not national composites, drawing, as they do today, men from all parts of the country. Most companies were made up of residents of the same town, at most the 


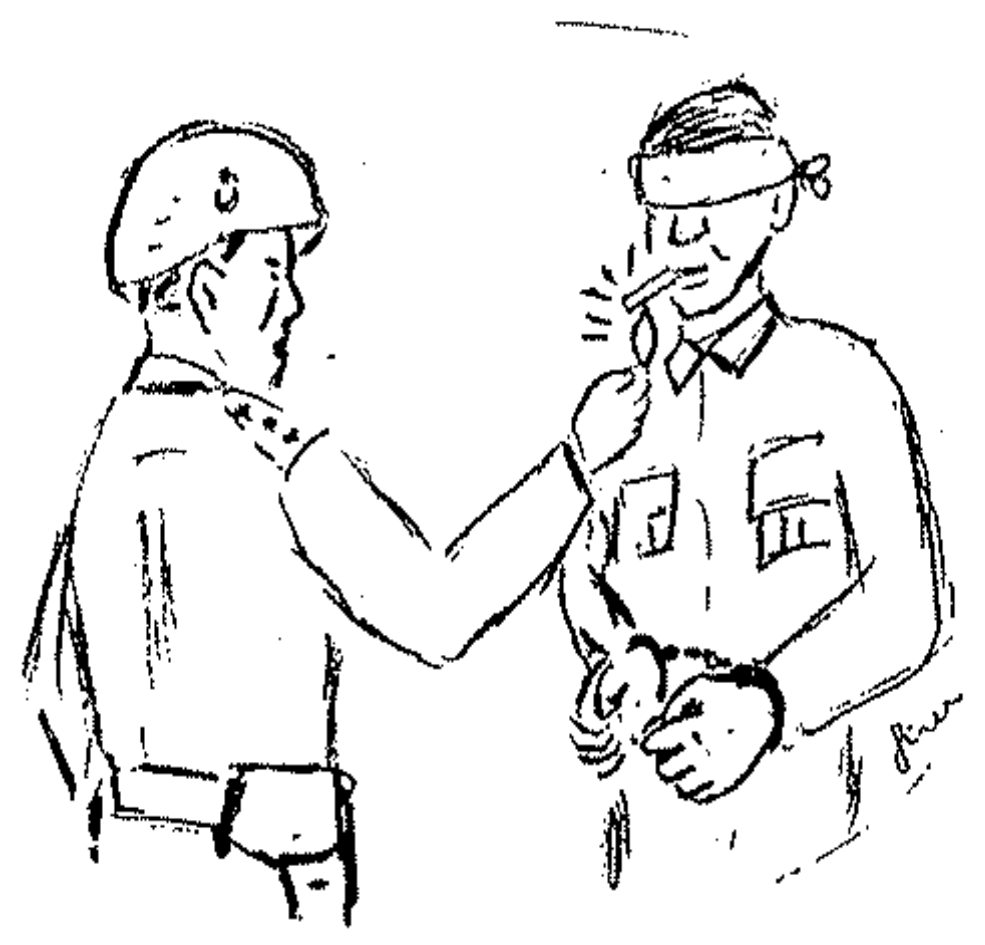

Figure 1. Ideally There Is No Place for Persecution in the Military, Where the Code of Ethics Should Always Prevail. Even a Prisoner of War Deserves Humanly Treatment and Is Interrogated With Dignity. Source: illustrated by the author.

same region, a situation that gave enlisted men a powerful leverage... In most cases, the captain had been elected by those in his company. Those in the ranks were his boyhood friends, and he expected to return to that small town to live in their midst and among their families once the war was over... And a certain lieutenant-colonel's attempt attempts to establish discipline simply aggravated insubordination. Some of the men drifted away for days, and those who remained refused to drill. (Linderman 1990: 27-30)

Linderman, a professor of military history, goes on to say that the army achieved a professional discipline when it shrank in size and professionalized after the Civil War. "That, however", he adds, "counted for little in the Spanish-American War, when the regulars were once again mandated by civilian volunteers, in number 10 times their own":

The novelist Sherwood Anderson was one of those volunteers in $1898 \ldots$ Anderson could not separate the company commander from the janitor he had known back in Ohio, or the first lieutenant from the celery raiser at home, or the second lieutenant from the knife-sharpener. And they did not control him: "An officer might conceivably get 'away' with some sort of injustice for the moment—but a year from now on, when we are all at home again..." (he wrote). But the Spanish-American War was the last of the hometown wars, and the power of command was strengthened dramatically by the experience of World Wars I and II. (Linderman 1990: 30-31)

As we learn from Janowitz, a trace of compatriotship exists even in the social life of the modern American officer:

Patterns of friendship are dominated by the military style of life. Many contacts involve no more than surface intimacy... In the mobile military community, friendship cliques develop on the basis of prior civilian geographical 
ties. Even the distinction between rebels ${ }^{2}$ and Yankees (the rest of the nation) still operates as an informal basis for inclusion and exclusion. (Janowitz 1960: 203-204)

So, seeking shelter in compatriots could be a commonplace and relatively innocent practice as well as a socially acceptable collective defense mechanism.

Among Turkish conscripts, it is a tremendous cohesive force and as such must even be implicitly recognized by officers as a fact.

\section{FACE-TO-FACE INTERACTION}

Some authors also stress weakness of secondary symbols and the importance of primary groups (a concept elaborated by Charles Horton Cooley), for fighting soldiers:

In the army, the soldier depends more and more on his military primary group. His spontaneous loyalties are to its immediate members... (While major ethical or political themes are important motivation sources for some volunteer armies) in a conscript army, political or social values and ethical schemes do not have much impact on the determination of the soldier to fight to the best of his ability. For the ordinary German soldier (the "hard-core" of National Socialists left apart), the decisive fact was that he was a member of a squad or section which maintained its structural integrity and which coincided roughly with the social unit which satisfied some of his major primary needs. (Shils and Janowitz 1956: 147)

\section{CONFLICTS DO ARISE OCCASIONALLY}

Beyond a certain point, inappropriate practices lead to open troubles in the unit. A very dangerous practice is the intense animosity focused on one or a few particular subordinates by a figure of authority. Some men are emotionally disturbed, immature, and passionate human beings. Thus, an ugly man might be jealous of a handsome man; a short man might have a grudge against a tall man; a "sissy" type of man might hate a muscular, virile-looking man; a man coming from a humble background might nurture spiteful feelings for a man from an upper status; and so forth.

An ill-willed person might be working for any organization, however, only a rigid and hierarchical environment like the army can give him the opportunity to inflict corporal and/or vehement psychological violence to others. Elsewhere his persecution of another person may occur in more subtle and less horrible forms and may even go unnoticed. After all, a director may pick on a certain clerk only by depriving him/her from a deserved promotion or by withholding an earned fringe benefit, etc., at most.

It should also be noted that while the military as an institution has similar aspects universally, each country has its own experiences and traditions, as well. Some social forces in the military may thus widely differ from one country to another. Changing times do bring new "flavors" into the environment, too.

For instance, Kirikkanat (1999), based on an article in Le Monde, writes that in Israel, the parents keep harassing the army authorities, always trying to be informed about the well-being of their sons and daughters (In Israel, young girls are also conscripted to serve in the army). Some parents are said to sue the army for the slightest pretexts. Generals are said to complain vehemently about all that nonsense.

Again, Moskos (1988: 8) notes that in Vietnam, the main conflict was between the young soldiers (conscripted by lotteries) and the former volunteers, the "lifers". So, it was basically a generation gap type of a matter. Moskos compares this situation with the Second World War days, when the conflict was essentially between the enlisted men and the officers.

A good commander is traditionally a fatherly character (see Figure 2). Lionel James, a foreign correspondent at the Balkan War, whose general attitude toward Turks is very negative, as it can be inferred merely from the title $^{3}$ of his book, nevertheless, admires the officer-enlisted man relationship in the late Ottoman army: 


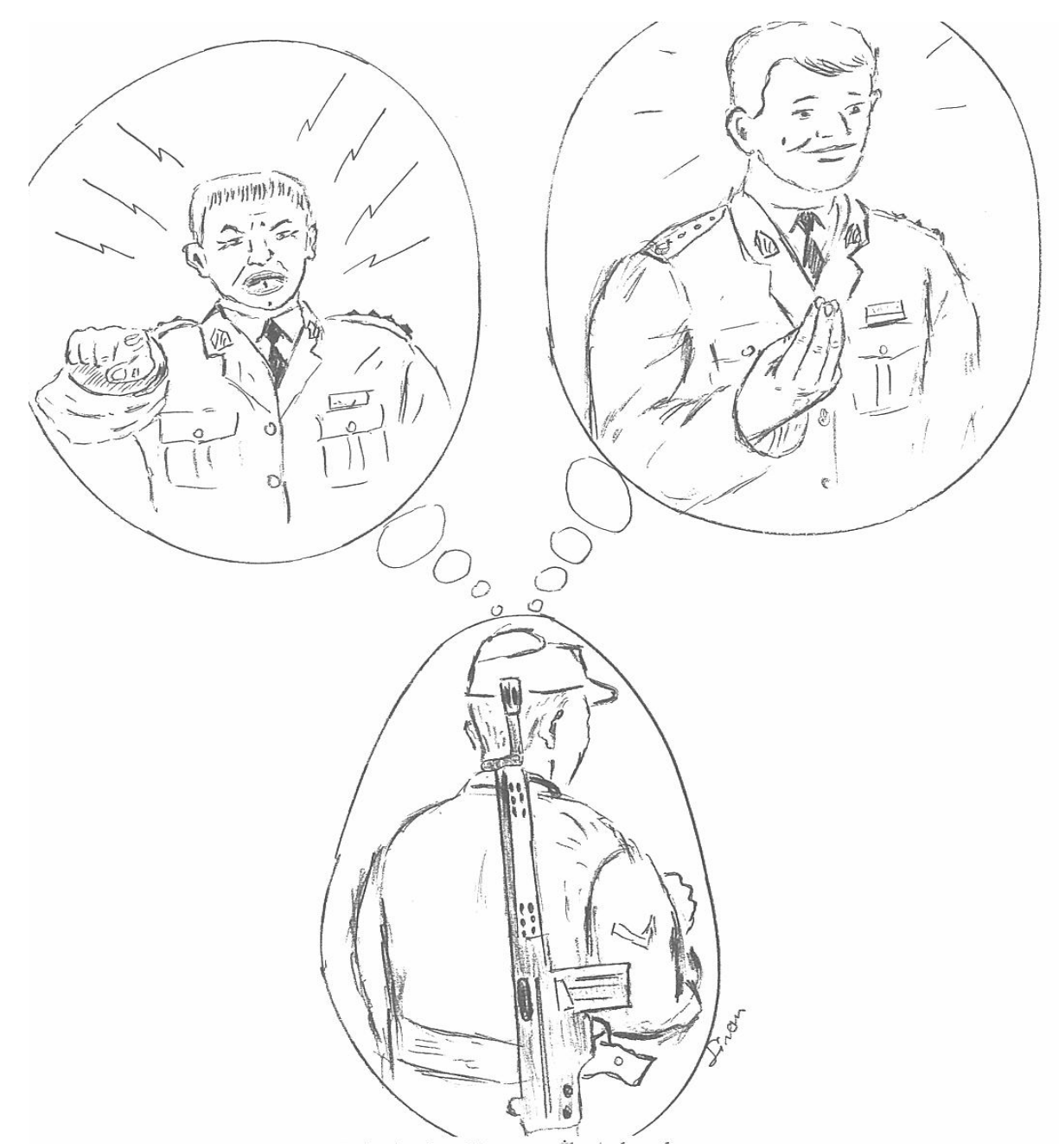

Figure 2. A Harsh Superior Leaves a Bad Memory. A Mild-Mannered Superior Causes a Sweet Memory to Be Remembered. Source: illustrated by the author.

There is something very brotherly in the intercourse between officers and men in the Turkish service. It must also be remembered that amongst Mohammedans, all men are equal in the eyes of God. This philosophy leads to an intimate intercourse between all ranks which could hardly be understood by those used to the European methods of enforced discipline. (James 1913: 199)

In his superb war novel All Quiet on the Western Front, Erich Maria Remarque makes us aware that in World War One, in the German Army, a substantial conflict was present between the enlisted men and the rank-holding personnel, especially the officers.
The former were quite jealous of the latter's privileges:

The senior private Kat once says: "If everybody had had the same food and the same salary, the war would have been over, long before!"4. Many allusions are made to the cruel sergeant, former postman Himmelstoss. On one occasion, he feels himself obliged to look nice to his men (as an exceptional situation). He then offers them "delicious meals, good only for the palate of an officer!" When the heroes of the novel are entrusted with the duty to protect a warehouse in an evacuated village, they have a feast. They drink from the coffee and smoke from the cigarettes and cigars, all of which had been destined for the officers. Then comes the 
time for brandy and rum! "If you ask Tjaden, we only lack the women in the officers' brothels now". (Remarque [1957] 1972: 40, 119, 196)

\section{PLEASANT YOUTH MEMORIES TO BE RECALLED}

Probably, the most sweet and becoming memories which men ordinarily tell about, pertain to their days in the military. Hardships and suffering which were hated then, later acquire delightful and pleasant dimensions. The unpleasant aspects are lost in oblivion and the nice parts are accentuated in the memories. The best of those nice memories relate to the comradeship ${ }^{5}$ enjoyed there. As sociologist Baltacioğlu (1994: 277) formulates it: "Once the recruit has gotten the military training, a great change is accomplished in his moral life. Why? Because in the military life, there is an ascending transition from disorderliness to discipline, from an arbitrariness to a legal pattern, and from selfishness to altruism".

It must be that intense altruism which renders the former military memories sweet and becoming.

An author even says that the veterans of the First World War actually missed those days later in their lives: "As a contrast with the previous wars, the Red Cross was generally respected. The wounded enemies were treated humanly. Reciprocal guarantees and international controls assured convenient conditions for the prisoners of war... (Later on) for numberless soldiers, return to the civilian life became deceiving, insipid, and sometimes insupportable... As those ex-soldiers grew older, they became more and more convinced that the war had been the best period of their lives: An era of comradeship and adventure, challenge and victories, economical security and absence of domestic responsibilities" (Howard 1988: 128). As a matter of fact, Howard goes on to say that this "nostalgia for an organized and respectable life aiming at a goal, constitutes one of the essential ingredients by which the political confusions of 1920's gave birth to diverse incarnations of fascism".

\section{SELF-SACRIFICE SERVES TO UNITE MEN}

The armed forces are entrusted with the most serious responsibility humanly ever possible: That of protecting the homeland, on the cost of donating lives of its members. A natural outcome of such an elevated mission is sacrifice. Sacrifice, besides being an outcome, is also a driving force for further continuation. As John Steinbeck puts it through the mouth of one of his novel ${ }^{6}$ characters, "the best way to get men into action (for a purpose) is to demand sacrifice from them".

That is just what the army and the other armed services do. Military life demands sacrifice from sleep, leisure time, relaxation, comfort, privacy, choice of food, and even personal pride (for the sake of elevating the national pride). Every single member has his own function in that complex.

A Sorbon-graduated former morale advisor of the Turkish Quartermaster School (Levazım Okulu) says the following: "Let us imagine the navy soldier in battle: The slightest mistake may send the whole crew down to the bottom of the sea. Because of this possibility, everybody in a battleship is obliged to take his task with the utmost seriousness. In such an environment, envy, selfishness, and personal ego commitments simply would not work" (Türkmen [1938] 1958: 300).

A prominent geology professor (who, in his childhood, had been the uniform-clothed mascot of the 223. Fleet in Yeşilyurt, İstanbul, and who had "flown" transportation planes at the age of five on the laps of officer-pilots) ${ }^{7}$ resumes the main points of military aviation in one sentence: Military aviation is the task of heroic people who think fast and discard the wrong thought right away, who are well-informed and who constantly refresh their knowledge, who are optimistic and who can trust one another (Şengör 1999). 


\section{CONCLUSIONS}

Service matures a young man and elevates his social status $^{8}$ in his native society, so the given sacrifice eventually is more than compensated. Military service is the modern equivalent of former initiation rites, transforming young people into real manhood.

\section{Notes}

1. On August 17, 1999, an earthquake happened at 3:00 a.m. in the morning in the Marmara Region. I was then staying with my wife in my mother-in-law's house in Scutari (Üsküdar), İstanbul. My sister-in-law was also present. We all woke up and rushed outside after the first tremblings. In front of the apartment building were other families gathered. The disaster brought us all together in a matter of a few hours. While waiting out there, friendly chats occurred among some neighbors, who, formerly, had even been ignoring one another on the main staircases and neglecting simple courtesy rules like saying "hello".

2. A former female American teacher of mine, Ms. Thompson, was from the northern state of Illinois. Once she said (San Antonio, 1987) that her father still called the southerners "rebels", as a reference to the days of the civil war. She said that old wounds can be difficult to forget, especially for the old people. Hemingway, in his novel For Whom the Bells Toll (1954), tells the story of a university lecturer from Montana, who joins the anti-fascist forces in the Spanish Civil War in mid-1930s. On one occasion, the hero remembers his paternal grandfather, who had been an officer in the Northern Army in American Civil War. His grandfather also referred to those days as the Rebellion War.

3. The title of the book is With the Conquered Turk. Another foreign correspondent, that of Daily Telegraph, Ashmead-Bartlett (1913: 101), writes the following about him in his work: "Lionel James (of Times), a charming companion, used to amuse himself by telling me horrible tales of the atrocities which the Turkish soldiers were likely to practice on me, in the event of their being defeated and getting out of hand". In fact, the Turks got defeated. But they did not lay a finger on James, who returned home safely and published his biased book (Ashmead-Bartlett's work is much more objective. Its title is In Thrace With the Turks).

4. The page numbers refer to the edition in French: a l'ouest rien de nouveau (All Quiet on the Western Front).

5. Even the author Türker (February 18, 1998), in his sarcastic article, has to admit the strength of comradeship when he talks about "male children, who have, acquired acquaintances in the scuffle of the army, acquaintances, which, for some with insufficient! Minds are destined to change into life-long friendships".

6. The novel is In Dubious Battle. Labor leader Mac and his assistant Jim help the delivery of a baby in a labor camp, in order to win the confidence of men. The men pool their efforts in preparing boiling water and providing white and clean laundry (shirts, underwear, etc.). The laundry obtained is more than enough. But Mac does not return the left-over pieces. Instead, he orders destruction of all, after the birth. Returning somebody's old shirt would have meant excluding him. Each man had felt his own contribution.

7. Professor Şengör later on kept visiting the base in his puberty years. He could not ever find that "marvellous mood anywhere else neither at home nor abroad".

8. A case history verifies this fact vividly: Some years ago, in a Thracian town in a coffee-house, a newly-discharged ex-soldier had trouble with an adolescent, who had attempted to bully the ex-soldier. The latter asked the adolescent: "First, tell me if you have done your military service"! After getting a "no" answer, he added: "In that case, I do not even accept you on an equal footing with me" (Öyleyse ben seni muhatap bile almam). Then, he simply walked away in dignity, leaving his opponent crestfallen.

\section{References}

Ashmead-Bartlett, E. 1913. With the Turks in Thrace. London: William Heinemann.

Baltacioğlu, I. H. 1994. Türk'e Doğru (Towards the Turk). Ankara: Publications of Atatürk Cultural Center.

Gray, J. G. 1970. The Warriors: Reflections on Men in Battle. New York: Harper \& Row Publishers.

Hemingway, E. 1954. Pour qui sonne le glas (For Whom the Bells Toll). Translated by D. V. Moppès. Coulommiers, Paris: Brodard et Taupin.

Howard, M. 1988. La guerre dans l'histoire de l'occident (War in the History of the Western World). Translated by D. Sénécal. Paris: Fayard.

James, L. 1913. With the Conquered Turk. Boston: Small, Maynard \& Company.

Janowitz, M. 1960. The Professional Soldier: A Social and Political Portrait. London: The Free Press of Glencoe, Collier-Macmillan Limited.

Kirikkanat, M. G. 1999. “Ana Var, Analık Var” (Genuine Mother Versus False-Mother). Radikal Newspaper, July 3, p. 2.

Linderman, G. F. 1990. "Military Leadership and the American Experience.” Military Review, April. 
Moskos, C. C. 1988. S.L.A. Marshall Chair: Soldiers and Sociology. United States Army Research Institute for the Behavioral and Social Sciences, U.S. Government Printing Office.

Remarque, E. M. 1957 (1972). à l'Ouest rien de nouveau (All Quiet on the Western Front). Translated by A. Hella and O. Bournac. Paris: Stock.

Şengör, A. M. C. 1999. "Uçan Makinelerdeki O Harikulâde Adamlar" (Those Wonderful Men Within the Flying-Machines). Cumhuriyet (Republic Newspaper), June 5, p. 3.

Shils, E. A. and M. Janowitz. 1956. "Primary Groups in the German Army." In Sociology: A Text With Adapted Readings, edited by L. Broom and P. Selznick. Evanston, I.L.: Row, Peterson \& Company.

Steinbeck, J. 1940. En un combat douteux (In Dubious Battle).
Translated by Ed. Michel-Tyl. Paris: Gallimard. Türker, Y. 1998. “Aç Aç Güzelleri” (The Beauties Who Open Up Before the Public). Radikal, February 15, p. 9.

Türkmen, F. 1938 (1958). Moral (Morale). Vol. 1. Ankara: Şahin \& Medeniyet Printing House (Falcon \& Civilisation Printing House.

\section{Bio}

Sinan Çaya, Ph.D., Instructor of Social Graduate Elective Courses, Institute of Marine Administration and Sciences, Istanbul University; research fields: rural sociology and peasant studies, military sociology, forensic social sciences, leadership, general education, social history, marine sociology, and marine organizational behavior. 